\title{
Circulation Research on China's Current Land Trust
}

\author{
Yu Tiankun ${ }^{1, a}$ \\ ${ }^{1}$ Beijing Jiaotong University, China \\ a469536579@qq.com
}

\begin{abstract}
Keywords: Land system, Land Trust Circulation, Policy Suggestion.
Abstract. China's "rural, agricultural and farmers" issues focus on rural land issues. In recent years there have been more serious waste of land resources in rural areas, which has increased the social instability. The trust mechanism in land circulation has become an innovative system in this background, has played an important role. In our country, the combination of rural land ownership and use rights, coupled with the flow of funds used by the land is too low, the land trust to try to promote the region more moderate. This paper analyzes the existing problems and realities of the existing land trusts from the perspective of the institutional basis and the current arrangement of land trust and circulation, and combs out the policy proposals to solve the relevant problems and understand the circulation of the land.
\end{abstract}

\section{Identify Some Concepts}

1.1 Land Transfer. Land transfer, that is the strict sense of the right to use agricultural land, is the right to transfer that farmers for the rural collective land. It refers to the land transfer to which the land debt is owned in this paper, which is the transfer of land contracting right.

1.2 Land Trust Flow. Land transfer folw is a new system in terms of land circulation. It refers to landowners or land settlors, for improving rate, effective use of land to land revenue, own land use rights by a trust system to give the trustee management, professional management and planning through the people will return to its operations as the owner of the land trust income.

\section{Data Analysis based on Questionnaire}

The author conducts field research and questionnaire according to the knowledge. In order to ensure the validity of the questionnaire, the validity analysis was carried out. After the test, the questionnaire has a good credibility, the data can be data analysis.

Regional survey from the agricultural point of view are the type of crop planting, demand for land is more loyal, the eastern city of Inner Mongolia - Hulunbeier, Xing'an, Tongliao, Chifeng, and the western city Bayannaoer is the main grain producing areas of Inner Mongolia, Hebei Cangzhou, Langfang for high-quality soybean production area, Handan, Xingtai, Cangzhou, Hengshui formed a high-quality cotton industry in Heilongjiang Longgang Basin.

2.1 Individual and Family. On the whole, the individual characteristics of the questionnaire are different, including the large age span, the large gap between the education level and so on.

Most of the samples were male (61\%), the age level is relatively concentrated in the middle age level. In terms of education, to accept nine years of compulsory education for the majority, only less than $5 \%$ of farmers have high school and above, belonging to the new farmer groups. The development of the family determines the individual development, for the farmers, the family population and the proportion of men and women determine the size of a family farmland and household income level, affecting the quality of life and multi-faceted development. The average number of households in the surveyed sample was 3.42, most of which was 3 to 5 households, accounting for $67.8 \%$ of the total. The average number of households surveyed was 2.45 , with 2 to 4 labor. More than half of the surveyed households' income level is in the average level of the region. 2.2 The Way of Land Trust Flows. From the Table 1, there are entrusted, leased, joint-stock, joint and other circulation methods, including $16.2 \%$ of the joint approach, commissioned way $9.8 \%$. 
Table 1. Trust circulation mode

\begin{tabular}{ccc}
\hline Way of circulation & Quantity & Proportion $(\%)$ \\
\hline Commissioned & 23 & 9.8 \\
\hline Rent & 45 & 13.7 \\
\hline Shareholding system & 50 & 15.2 \\
\hline joint & 53 & 16.2 \\
\hline Other & 148 & 45.1 \\
\hline
\end{tabular}

Except the way of the circulation has been marked in the questionnaire, there are a large number of farmers choose the "other", which is not listed in the questionnaire. Some farmers will carry out seasonal land circulation, the land will be maximized use.

2.3 The Reasons for Farmers to Carry out Land Trus. The main reason for the transfer of land trust is that agricultural efficiency is disproportionate to agricultural cost, and the phenomenon of abandonment is serious, which causes the serious state of cultivated land idle. $75 \%$ of the land trust is initiated by decentralized farmers, with more causes for agricultural benefits $(23.8 \%)$ and overburdened labor (20.4\%).

In contrast to the flow of households, the main reason for the land entrants to land trust is the opposite of the flow of households, and the inflowers believe that the land trust is to earn more land management benefits and to use the labor force at home.

Through the comparison between the households and the influent households, it can be seen that the land circulation is mostly scattered farmers with the existing reasons, which causes the characteristics of the small and slow progress of land circulation. This feature is not conducive to the circulation of land trust development of.

\section{The Main Problems of Land Trust Circulation in China}

Although the development of agricultural industry has made great progress, and the government have given some support from the relevant policies. China's land trust has developed some new features, but there are still some problems, it is difficult to adapt to the needs of modern agricultural development. The main problems include the defects of the existing household registration system, the difficult difficulty of the land intermediary to adapt to the needs of land circulation, the inability to coordinate the distribution of benefits, the persistence of the traditional concept of land care and the unreasonable arrangement of contractual assignment of land trust.

\section{Suggestions on the Circulation of Land Trust in China}

Internationally, land trust flows mainly in the United States land protection trust and community type land trust and Japan's sale of land trust and lease type land trust. The four types of land trusts are mainly based on the privatization of land, and there is a difference in the nature of land property rights in China, but it is of great significance for the development of land trust in China.

In foreign countries, the relationship between finance and land trust circulation is relatively close, which is not matched with the development of rural finance and rural land trust in china. In order to develop the development of land trust, we can increase the supply of rural finance, change the current situation of single form, and change the single form into diversified mode.

4.1 Establish and Improve the Corresponding Laws and Regulations. Mainly to strengthen the micro-level construction mechanism, should be the current land trust circulation problems introduced more specific legal system, and strive to achieve not only in the macro aspects of guidance, more at the micro level of operational recommendations and guidance. At the same time increase the intensity of land trust propaganda. At the same time, improve the rural social security system, to solve the functional departments of the organization and coordination, unified protection. 
4.2 Increase the Intensity of Land Trust Propaganda. Chinese Academy of Social Sciences in the 2016 land report pointed out that in the new year of land trust survey, less than 20 percent of farmers understand the land trust, farmers as farmers with the right to operate Lack of awareness of the existing trust model and the role of land transfer. If farmers lack the basic understanding of the advantages and safeguards of trust, this will lead to the development of land trust circulation.

Faced with this problem, all levels of government should update the land transfer of the relevant policies at the same time, increase the farmers for the land circulation propaganda efforts. The trust company should take the initiative to cooperate with the government to carry out the popularization of the propaganda of the circulation of the land trust, summarize the actual experience of the region where the trust of the land trust has been successfully carried out. As a case, the trust and the relevant advantages, For the rural land trust to lay a solid ideological foundation.

4.3 Improve Land Intermediary. From the management and production efficiency of China's land and the interests of national property, the society must establish a micro-market-oriented land operation mechanism based on the national macro-control, and need to design a system to play a role just like lubricant. Therefore, it is necessary to further improve the land intermediary service organization, the establishment of a land intermediary for the land to the land side and the land out of both ends of the dumbbell-type land circulation mechanism, establish and improve the land organization, land services, land transfer agency system and service system. For the land supply and demand sides to provide trade information, in order to achieve land transfer, to provide rapid land management, efficient land transfer operation mechanism.

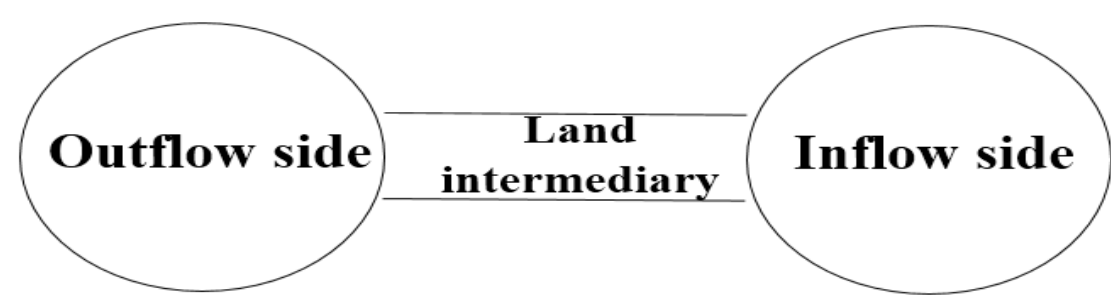

Fig.1. Dumbbell-shaped land transfer mechanism

\section{Conclusion}

The transfer of land trust is closely related to the vital interests of farmers. However, due to the relatively slow development of land trust in China, the development of land trust is relatively slow and has a large gap with international advanced model. This is not only caused by our country's land ownership model, the existing institutional arrangements and contract basis, but also by the social form, land use and civic ideology and so on.

\section{References}

[1] Land Trust Alliance. Land Trust Standards and Practices[S]. 2004.

[2] Donald M. Mcleod. Jody Worshaye and Dale J. Menkhaus. Facttors influencing Support for Rural Land Use Contril: A Case Study[J]. Agricultural and Resources Economics Review. April 1999, 44-46.

[3] Karen A. Gary. Community Land Trusts in the United States[J]. Journal of Community PractICe, 2008, 16(1).

[4] Mark A. Sunderman, Ronald w. Spahr. Management PolICy and Estimated Returns on School Trust Lands[J]. The Journal of Real Estate Finance and EconomICs, 2006,33(4). 
[5] Liu Zhiren [1], Zhang Xuan [1]. Foreign Rural Land Trust: Research Status and Reference. Finance and Economics Theory and Practice, 2007,28 (2); 14-18

[6] Shen Bin. Value Orientation and Institutional Choice of Land Contractual Management Right Transfer. Journal of Shanxi Agricultural University: Social Science Edition, 2016,15 (1); 25-32

[7] Liu Yu. There are some problems in the circulation of rural land contract management right and its perfection. Journal of Hunan Institute of Socialism, 2015,16 (6); 73-75

[8] Deng Weijie. Discussion on the Circulation of Land Contractual Management Right. Journal of Zhejiang Wanli University, 2015,28 (6); 20-24r 